\title{
Effects of Curcumin on Sodium Arsenite Induced Neoplastic Cell Transformation in Balb/c 3T3 Cells
}

\author{
Busra Demircioglu ${ }^{1}$ \\ https://orcid.org/0000-0002-3100-8166
}

Yasemin Aydin ${ }^{2}$

https://orcid.org/0000-0002-4338-4687

\section{Banu Orta-Yilmaz ${ }^{2}$}

https://orcid.org/0000-0002-8006-1107

Nebahat Yildizbayrak ${ }^{2}$

https://orcid.org/0000-0001-8724-8620

\author{
Melike Erkan ${ }^{2 \star}$ \\ https://orcid.org/0000-0002-6906-4753
}

${ }^{1}$ Istanbul University, Institute of Graduate Studies in Sciences, Department of Biology, Istanbul, Turkey; ${ }^{2}$ Istanbul University, Faculty of Science, Department of Biology, Istanbul, Turkey.

Editor-in-Chief: Paulo Vitor Farago

Associate Editor: Paulo Vitor Farago

Received: 2020.02.17; Accepted: 2020.09.10.

${ }^{*}$ Correspondence: merkan@istanbul.edu.tr; Tel.: +90-530-6615447 (M.E.)

\section{HIGHLIGHTS}

- Sodium arsenite can cause neoplastic transformation in cells.

- Curcumin reduced cell viability and increased LDH activity in transformed Balb/c 3T3 cells.

- Curcumin caused DNA damage in transformed Balb/c 3T3 cells.

- Curcumin may play a protective role in sodium arsenite-induced toxicity.

Abstract: Arsenic is a toxic substance that spreads widely around the environment and accumulates as metalloid in the earth's crust. Arsenic and its derivatives are found in drinking water, nutrients, soil, and air. Exposure to arsenic is associated with lung, blood, skin cancer and various lesions. Curcumin is a polyphenolic compound derived from Curcuma longa (turmeric) rhizome and is one of the main curcuminoids. Curcumin is known to be antioxidant, antibacterial, anti-inflammatory, analgesic effects. This study aimed to investigate the potential of sodium arsenite to transform embryonic fibroblast cells and to evaluate the cytotoxic and genotoxic effects of curcumin in neoplastic transformed cells. Neoplastic cells transformation was induced by sodium arsenite in Balb/c 3 T3 cells at the end of 32 days. After transformation assay, the transformed cells were treated with various concentration of curcumin to evaluate cell viability, lactate dehydrogenase activity and DNA damage for $24 \mathrm{~h}$. The results revealed that curcumin decreased cell viability and increased the activity of lactate dehydrogenase enzyme in neoplastic transformed Balb/c 3T3 cells. In 
conclusion, the results demonstrated that curcumin has an anticancer effect on neoplastic transformed Balb/c 3 T3 cells by causing DNA damage.

Keywords: cancer; curcumin; embryonic fibroblast cells; genotoxicity; sodium arsenite.

\section{INTRODUCTION}

Arsenic is a heavy metal and major environmental toxicant with various deleterious effects in animal and human health [1]. Arsenic is also found in commercial and industrial products such as pesticides, drugs, wood preservatives, glass, paper and semiconductors [2]. Drinking water is the most common route of arsenic exposure and safety levels of arsenic were limited $10 \mu \mathrm{g} / \mathrm{L}$ by the World Health Organization [3]. Arsenic has been classified by the International Cancer Research Agency as a group I human carcinogen and it is estimated that over a hundred million people in the world are exposed carcinogen concentrations [4]. Previous studies demonstrated that arsenic had a genotoxic effect causing chromosomal abnormalities [5]. It caused changes in apoptotic gene expression and had adverse effect on intracellular signal transduction pathways [6]. Arsenic affected cell growth and proliferation and inhibited the regulation of DNA repair systems [7]. Chronic arsenic exposure in human bronchial epithelial cells and rat liver epithelial cells resulted in increasing on growth rate of cells and their morphology has been transformed to malignant cell [8]. In another study with Balb/c 3T3 embryonic fibroblast cells which was exposed to arsenic, has shown neoplastic transformation. Thus, studies demonstrated that arsenic was shown carcinogenic effect on different cell lines [9].

Curcumin, a polyphenolic compound derived from the rhizome of Curcuma longa (turmeric), a perennial plant of Southeast Asia, primarily India and China [10]. Curcumin is the main curcuminoid and is responsible for the yellow color of the spice. It has antioxidant, anti-inflammatory, antibacterial, analgesic and wound healing activity of this natural polyphenolic plant pigment. [11]. In Southeast Asian countries, turmeric spices are often consumed, have been reported to have a lower incidence of most cancers than other countries [12]. It has been reported that curcumin reduces genotoxicity and shows chemo- preventive effects against arsenic on lymphocytes isolated from healthy individuals or from donors with chronic arsenic exposure [13,14]. Since curcumin has a strong antioxidant and free radical scavenging properties, it can prevent the initiation of carcinogenesis [15]. It suppresses the proliferation of cancer cells and inhibits the expression of antiapoptotic proteins and stimulates apoptosis. In a previous report clearly demonstrated that curcumin showed anticarcinogenic property on cancer cells by inhibiting metastasis and angiogenesis [16]. In studies, curcumin has been shown to induce cell death in many animal and mammalian cell cultures such as breast, lung, colon, kidney, ovary, leukemia, melanoma [17]. In addition, curcumin does not have a toxic effect on healthy cells, also suppresses the proliferation of tumor cell types by various mechanisms. Thus, curcumin may be an attractive source for drug development studies in various types of cancer [12].

This study aimed to investigate the sodium arsenite-induced neoplastic cell transformation in Balb/c 3T3 embryonic fibroblast cells and identify the anti-proliferative activities with explore genotoxicity induction of curcumin on transformed cells. For this purpose, neoplastic cell transformation with sodium arsenite was performed in Balb/c 3T3 embryonic cells. Different concentrations of curcumin were applied to the transformed Balb/c 3T3 cells to investigate cell viability, lactate dehydrogenase enzyme activity and DNA damage.

\section{MATERIAL AND METHODS}

\section{Experimental design and cell culture}

The 3T3 embryonic fibroblast cell line used in the experiment is a non-tumorigenic cell line derived from 14-17 days pregnant Balb/c mice. The embryonic fibroblast cell line was bought from American Type Culture Collection: The Global Bioresource Center to our laboratory and was maintained under in vitro conditions with regular passage one to two times a week. Cells were grown in Dulbecco's modified Eagle's medium (DMEM) culture medium supplemented with 1\% PSA (Penicillin-Streptomycin-Amphotericin), 10\% calf serum, $4.5 \mathrm{~g} / \mathrm{L}$ glucose, L-glutamine and sodium pyruvate and under a humidified incubator of $5 \% \mathrm{CO} 2$ in air at $37^{\circ} \mathrm{C}$.

In the initiation phase of the morphological transformation assay the concentration of sodium arsenite (purity $\geq 90 \%$, Merck, Darmstadt, Germany) applied to Balb/c 3T3 cells was determined on the basis of the study conducted by Takahashi and coauthors [18]. Cells were exposed to $10 \mu \mathrm{M}$ concentration of sodium 
arsenite which stimulating morphological change in cells and causing carcinogenic effect. The cells in the control group were exposed to only normal cell medium. 12-O-tetradecanoylphorbol-13-acetate (TPA) used in the promotion phase of the cell transformation assay was prepared in dimethyl sulfoxide (DMSO) at a concentration of $0.1 \mu \mathrm{M}$ [19]. Curcumin (purity $\geq 98.0 \%$, Merck, Darmstadt, Germany) was dissolved in DMSO and treated to cells at $5,7.5,10,15$ and $25 \mu \mathrm{M}$ concentrations, which are concentrations that show anticancer activity against environmental toxins in different cancer cell lines [20,21]. Then, $I C_{50}$ concentration of curcumin was calculated according to 3-(4,5- dimethylthiazol-2-yl)-2,5-diphenyltetrazolium bromide (MTT) test results and used in the cytotoxicity and comet tests.

\section{Transformation assay}

The cell transformation experiment was exerted according to the protocol specified in a previous study [17]. As noted in the protocol, cells were seeded in six-well plate with $8 \times 10^{3}$ cells per well and incubated for $24 \mathrm{~h}$ at $37^{\circ} \mathrm{C}$. The assay was comprised of two steps, the initiation and promotion phases, and the assay lasted 32 days. The cells in the experimental group were exposed to $10 \mu \mathrm{M}$ sodium arsenite in Eagle's minimal essential medium (MEM) medium containing 10\% fetal bovine serum (FBS), $1 \%$ PSA in the initiation phase during $72 \mathrm{~h}$. Between Day 4 and 7 , the cells were taken into fresh medium without sodium arsenite. In the second phase, called the promotion stage, the cells were transferred to Ham's F12 and Dulbecco's modified Eagle's medium (DMEM/F-12) containing 2\% FBS, $1 \%$ PSA and $2 \mathrm{mg} / \mathrm{mL}$ ITES and were exposed to $0.1 \mu \mathrm{M}$ TPA on the day $7,11,14$ and 17 . On day 21 , the cells were replaced in fresh media and the media is changed twice a week until the Day 32. The cells in the control group were treated with normal cell growth medium throughout the experiment. Giemsa staining was performed on the Day 32 and the cells were examined by stereomicroscope (Lecia M205A, Leica, Wetzlar, Germany).

After the examination, more than 50 cells and cell foci larger than $2 \mathrm{~mm}$ in diameter were evaluated. In addition, the cells showing type III foci among these cells were considered as transformed cells. The identification of type III foci cells was based on: i) spindle-dense basophilic stained cells, ii) cells that grow in multilayer form differently than the basic cell layer, iii) cells with random orientation, and iv) cells growing invasive in the foci corners [22].

\section{Cell fixation and Giemsa Staining}

After 32 days, the cells were washed twice with PBS (1:1) and fixed for 3 min with a PBS / methanol mixture. After fixation, the cells were treated with $100 \%$ cold methanol for 10 min and then washed twice with methanol. Then Giemsa Staining was performed to identify cells with potential for tumor formation. One $\mathrm{mL}$ of Giemsa dye and $3 \mathrm{~mL}$ of distilled water was added to each well and washed in a shaker for 10 min which was repeated 5 times. After air drying, the cells in the wells were examined by fluorescent attachment microscope with UV filter equipment (Olympus IX71, Tokyo, Japan).

\section{Cell viability by MTT assay}

To determine the IC50 value of curcumin in neoplastic modified cells and to demonstrate the effects of curcumin in normal 3T3 cells, the MTT test which determined cell viability was performed according to the kit protocol (Roche Diagnostics, Mannheim, Germany). Cells were seeded on 96-well culture plates with $5 \times 10^{3}$ cells per well. After completion of the curcumin exposure, $10 \mu \mathrm{L}$ of MTT I solution was added to each well and the plates were incubated for $4 \mathrm{~h}$ at $37^{\circ} \mathrm{C}$ in a $\mathrm{CO}_{2}$ incubator to convert the MTT dye into water-insoluble formazan crystals. MTT II solution $(\mu \mathrm{L})$ was added to each well to dissolve the formazan crystals generated by viable cells and overnight in the $\mathrm{CO}_{2}$ incubator. The optical density of the cells was measured spectrophotometrically using an ELISA plate reader at a wavelength of $540 \mathrm{~nm}$. Viability results were expressed as percentage in experimental cells, with $100 \%$ control cell viability not treated with the test solution. Half-maximal response concentration $\left(\mathrm{IC}_{50}\right)$ of curcumin was determined by using the GraphPad prism program.

\section{Cytotoxicity by LDH assay}

To determine the cytotoxicity and cell membrane damage the Cytotoxicity Detection Kit (LDH) (Roche Diagnostics, Mannheim, Germany) was applied following the kit protocol. $10^{4}$ cells per well seeded in 96 -well culture plates and cells were incubated with six different concentrations of curcumin $24 \mathrm{~h}$. After completion of the experiment period $100 \mu \mathrm{L}$ supernatant transferred to new plate and $100 \mu \mathrm{L}$ mixture of dye and enzyme solutions was applied to each well. The results were obtained by measuring the absorbance of the increasing 
color of the red formazan product on the spectrophotometer at a wavelength of $492 \mathrm{~nm}$ according to the cytotoxicity after $30 \mathrm{~min}$ of incubation.

\section{Alkaline comet assay}

To determine the effects of curcumin against genotoxicity resulted from sodium arsenite induced transformation, comet assay method used in this study [23]. Neoplastic modified Balb/c 3T3 embryonic fibroblast cells were seeded in 24-well culture plates with $1 \times 10^{5}$ cells per well and incubated at $37^{\circ} \mathrm{C}$ for 24 h. Next the cells in the experimental group were exposed to $\mathrm{IC}_{50}$ concentration of curcumin for $24 \mathrm{~h}$. $\mathrm{H}_{2} \mathrm{O}_{2}$ was used as a positive control to induce DNA damage. After the exposure period was completed, the cells were treated with trypsin, and after centrifugation suspended in PBS. Cells were mixed with $0.5 \%$ low melting point agarose and dropped on slides pre-coated with $1.5 \%$ normal melting point agarose at $4{ }^{\circ} \mathrm{C}$ for 30 min. To remove cellular proteins and membranes slides immersed to lysis solution (100 mM EDTA, $2.5 \mathrm{M} \mathrm{NaCl}$, $10 \mathrm{mM}$ Tris, $1 \%$ triton-x 100 and $\mathrm{pH}: 10)$ at $4{ }^{\circ} \mathrm{C}$ for $1 \mathrm{~h}$. To prevent DNA damage all steps from the lysis process were carried out in the dark room. Slides were then placed in fresh electrophoresis buffer $(300 \mathrm{mM}$ $\mathrm{NaOH}$ and $1 \mathrm{mM}$ EDTA, pH > 13) for DNA unwinding for 20 min before electrophoresis at $25 \mathrm{~V}$ and $300 \mathrm{~mA}$ for 30 min using an electrophoresis power supply (BioRad) at $4^{\circ} \mathrm{C}$. Then slides rinsed three times 5 min each with neutralization buffer (0.4 M Tris, $\mathrm{pH} 7.5)$. For staining, slides were firstly washed with distilled water and stained with DAPI at $2 \mu \mathrm{g} / \mathrm{mL}$. Scoring of test performed with fluorescent attachment microscope. Randomly select 100 cells of each groups were analyzed for tail length, tail \% DNA and olive tail moment with using CometScore2.0 software.

\section{Statistical analysis}

The statistical program used for the statistical evaluation of the data is GraphPad Prism 5.0 (GraphPad Software, San Diego, CA, USA). Results were compared by one-way analysis of variance (ANOVA) and Tukey's multiple comparison post hoc testing was performed. For statistical analysis results were expressed as the means \pm standard errors of triplicate samples, and the reproducibility was confirmed in three different experiments. $p<0.001, p<0.01$ and $p<0.05$ were defined to be a statistically significant difference between the groups.

\section{RESULTS}

\section{Transformation assay results}

Morphological transformation was observed in the embryonic fibroblast cells as a result of sodium arsenite and TPA stimulation of cells. The images taken on day 4, 11, 21 and 32 were given in Figure 1 to describe the morphological changes observed in cells over time during the transformation assay. In addition, spindle-to-round conversion was observed in cell morphologies when compared between days 1 and 32 of transformation assay (Figure 2). On day 32, cell nuclei and cell size were larger and nuclear granules were also more in sodium arsenite treated groups than control. Neoplastic morphological changes in cells were significant in the experimental group exposed to sodium arsenite and TPA, whereas no changes were seen in the morphology of the cells in the control group (Figure 3). From day 21, cells showed a spindle shape and random orientation. When the experiment period was completed on day 32 cells were stained with giemsa and examined under microscope. During microscopy abnormal proliferated cells that showed cancer cell morphology which are multilayer cells called foci was observed, however there was no change in the growth potential and morphology of the cells in the control group. 


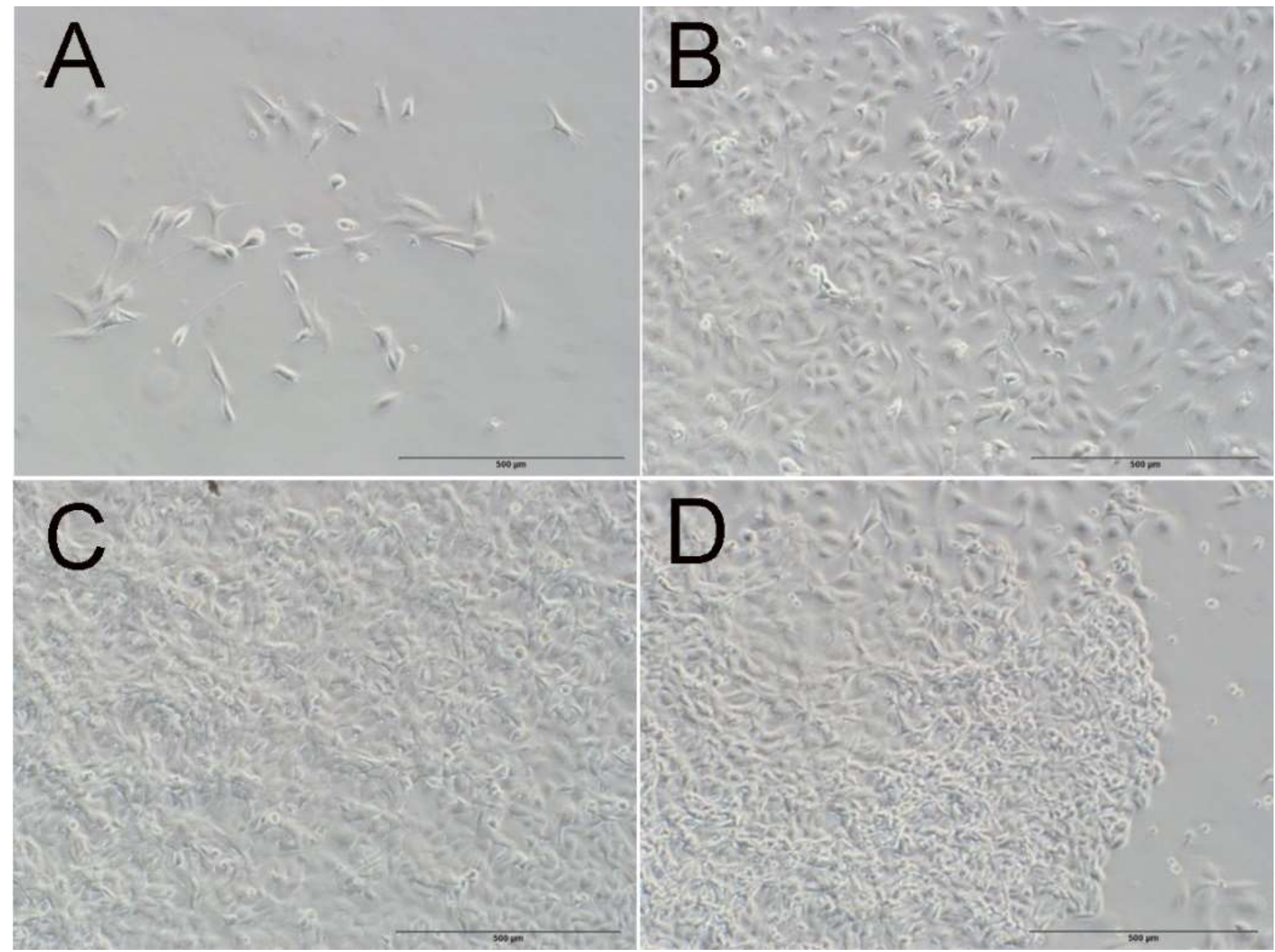

Figure 1. Images demonstrate the morphological changes of Balb/c 3T3 cells at day 4 (A), day 11 (B), day 21 (C) and day 32 (D) of transformation protocol.

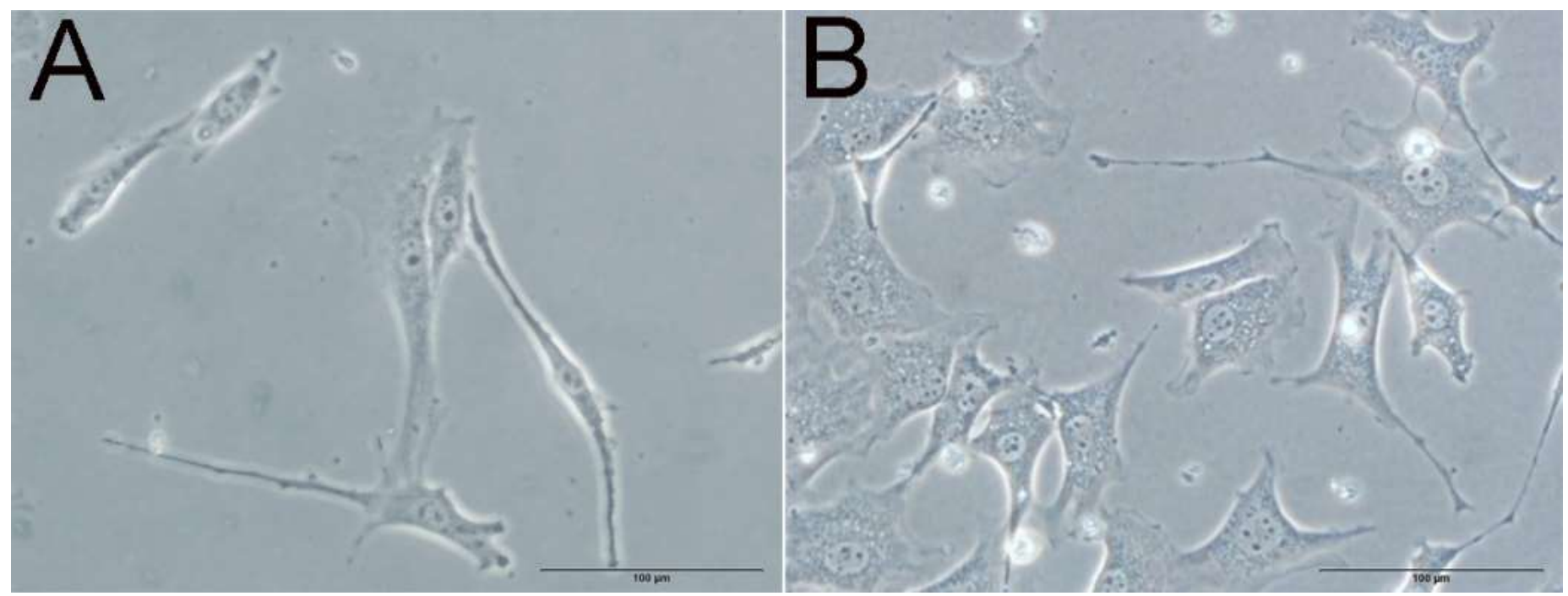

Figure 2. Morphological changes as a result of sodium arsenite exposure observed on the day 1 and 32 of the transformation assay in Balb/c 3T3 cells. 


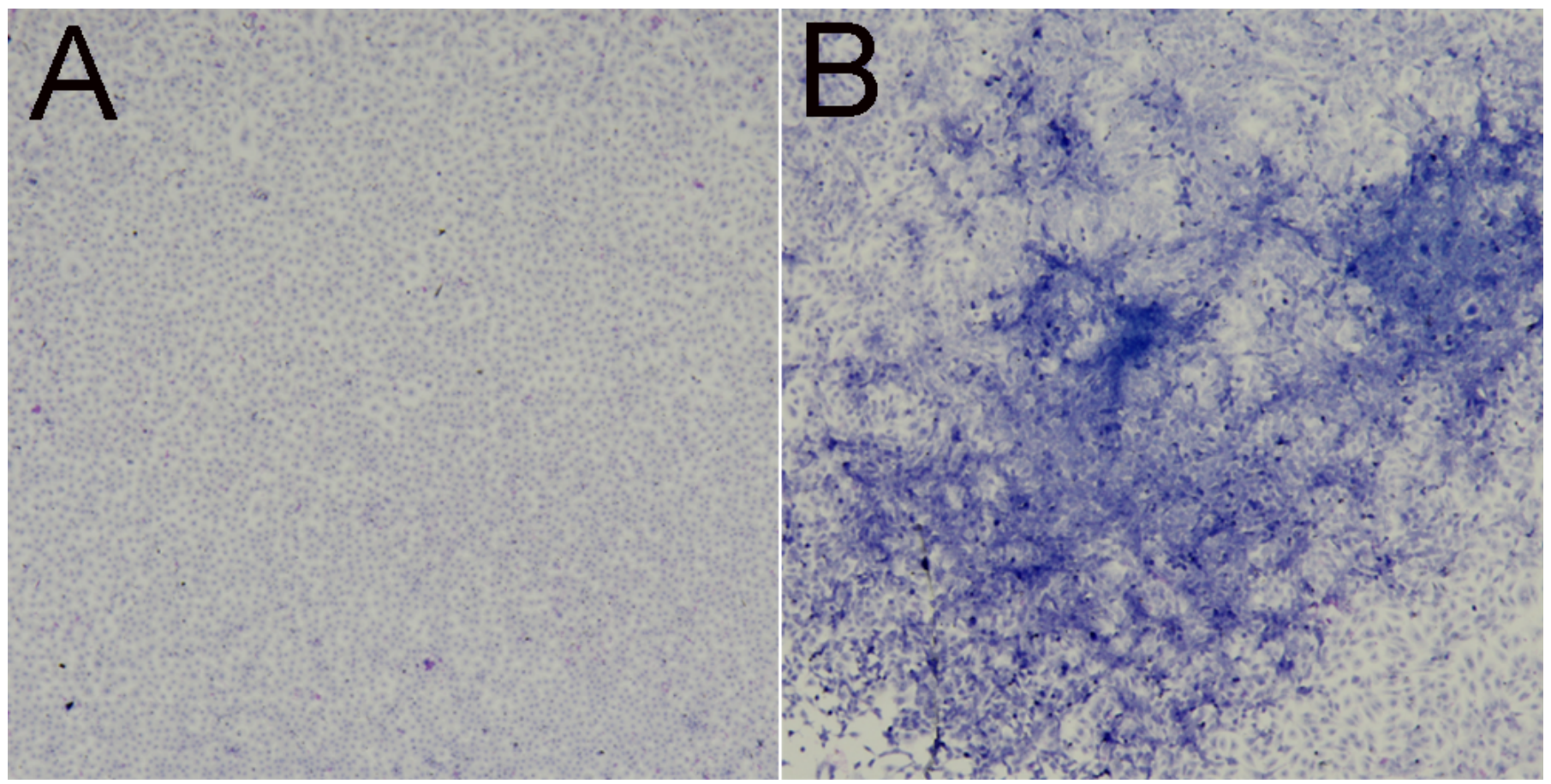

Figure 3. Images obtained as a result of a 32-day transformation assay in Balb/c $3 T 3$ cells. (A) normal cells not administered sodium arsenite (B) neoplastic cells that transformed to foci by treatment with sodium arsenite. $(50 \times$ magnification).

\section{Cell viability results}

The effects of curcumin concentration used in neoplastic modified cells on cell viability in normal 3T3 embryonic fibroblast cells were presented in Figure 4. In 3T3 embryonic fibroblast cells, curcumin did not cause any significant changes in cell viability at 5, 7.5, 10, 15 and $25 \mu \mathrm{M}$ concentrations. As shown in Figure $5 \mathrm{~A}$ the effect of six different concentrations of curcumin on neoplastic modified 3 T3 embryonic fibroblast cells were measured after $24 \mathrm{~h}$ treatment. After experimental period there was a significant decrease on cell viability from $7.5 \mu \mathrm{M}$ and above concentration of curcumin $(p<0.001)$. Furthermore, $I_{50}$ concentration of curcumin was detected as $15.76 \mu \mathrm{M}$.

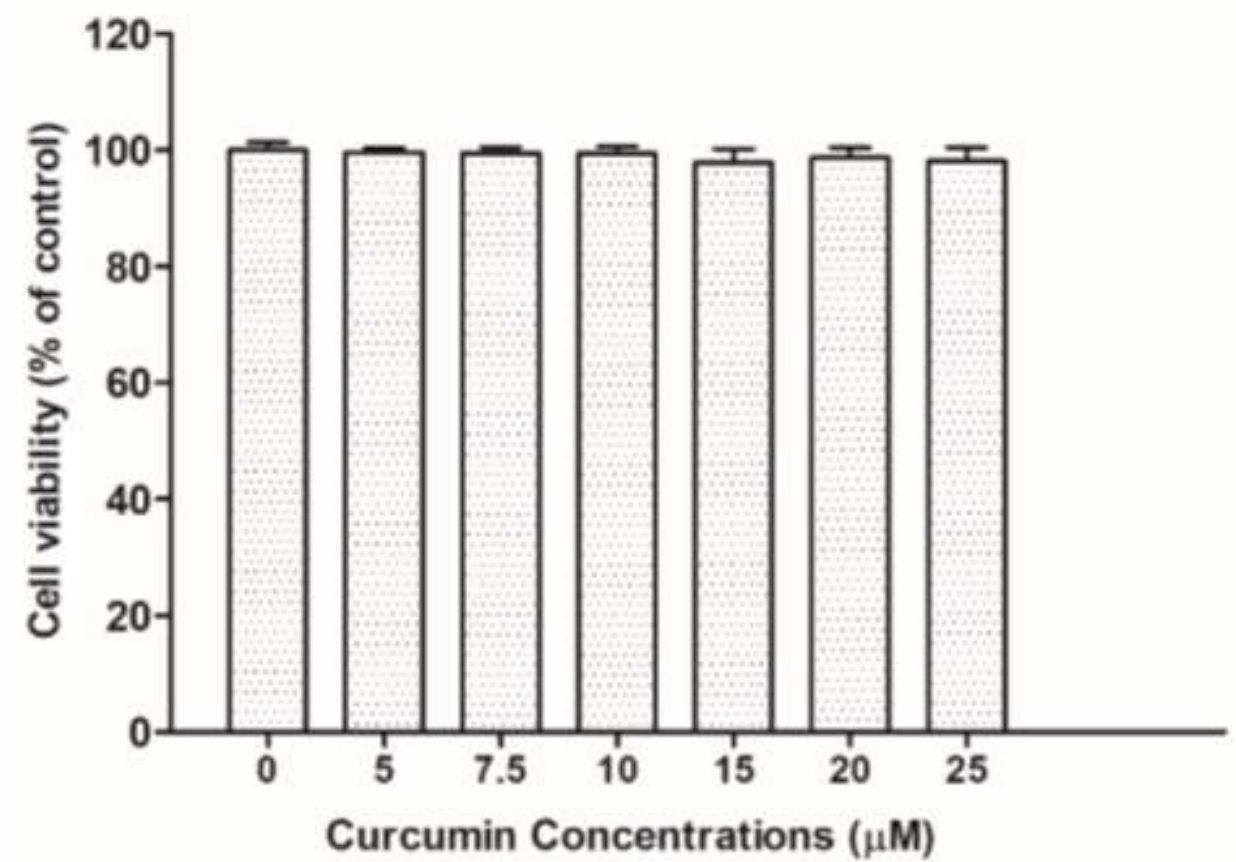

Figure 4. Concentration-dependent effects of curcumin on cell viability for $24 \mathrm{~h}$ in Balb/c $3 T 3$ cells. Each value indicates mean \pm SEM of three independent three replicate experiments. 


\section{Cell cytotoxicity with LDH assay}

According to LDH test results after the 24 hours treatment with curcumin, it was shown that there was significant increase at $15 \mu \mathrm{M}$. and above concentration of curcumin (Figure $5 \mathrm{~B})(\mathrm{p}<0.001)$.
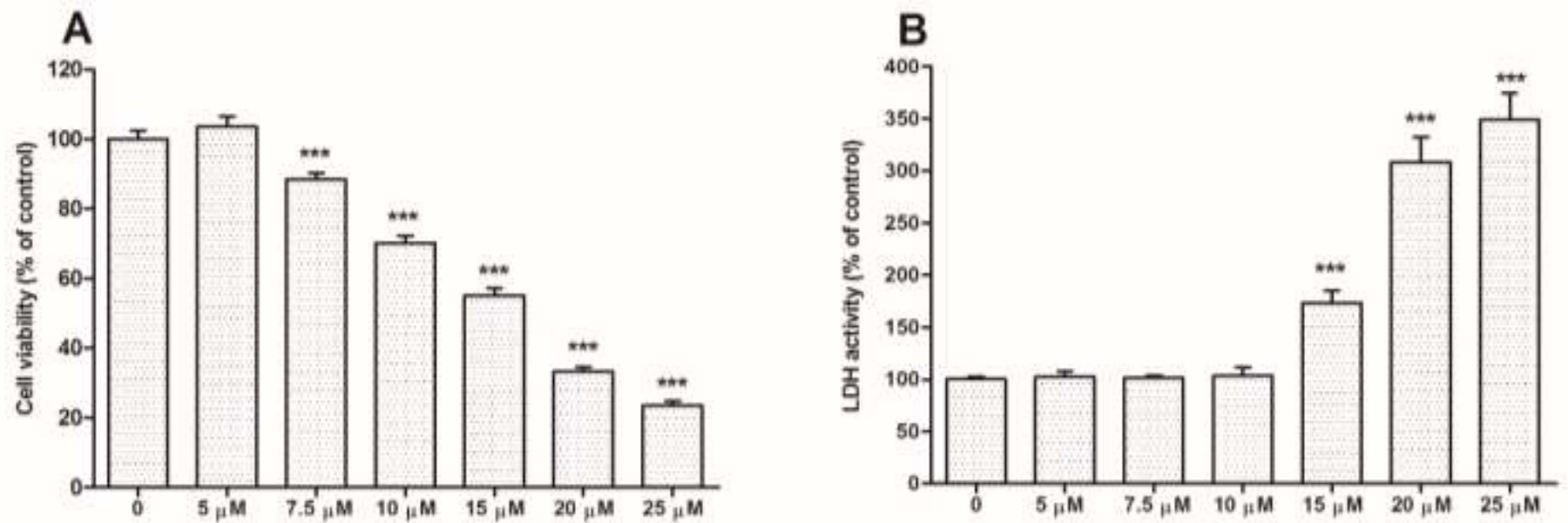

Figure 5. Concentration-dependent effects of curcumin on cell viability $(A)$ and lactate dehydrogenase activity $(B)$ for $24 \mathrm{~h}$ in neoplastic transformed Balb/c 3T3 cells by sodium arsenite. Each value indicates mean \pm SEM of three independent three replicate experiments. Significance at ${ }^{* *} p<0.001 .\left(^{*}\right)$ Compared with control group.

\section{Comet assay results}

Comet assay was performed to determine the genotoxic potential of curcumin on the neoplastic transformed 3T3 embryonic fibroblast cells. In comet assay, curcumin had a significant genotoxic effect in the neoplastic cells. As shown in Table 1 and Figure 6 tail length, tail \% DNA and olive tail moment results were significantly increased at curcumin exposed neoplastic transformed 3T3 embryonic fibroblast cells $(p<0.05)$.

Table 1. Effects of curcumin on DNA strand-breaks in neoplastic transformed 3 T3 embryonic fibroblast cells by sodium arsenite.

\begin{tabular}{llll} 
Groups & Tail \% DNA & Olive Tail Moment & Tail Length $(\mu \mathrm{m})$ \\
\hline Control & $31.03 \pm 1.05$ & $57.02 \pm 1.62$ & $3.92 \pm 1.08$ \\
$\mathrm{H}_{2} \mathrm{O}_{2}$ & $72.38 \pm 1.18^{*}$ & $95.47 \pm 1.27^{*}$ & $11.17 \pm 1.63^{*}$ \\
Curcumin & $40.18 \pm 1.15^{*}$ & $61.42 \pm 1.08^{*}$ & $5.03 \pm 0.96^{*}$
\end{tabular}

Significance at ${ }^{*} \mathrm{p}<0.05,\left({ }^{*}\right)$ compared with control. Each value indicates mean \pm SEM of three independent three replicate experiments. $\mathrm{H}_{2} \mathrm{O}_{2}$ : Positive control.
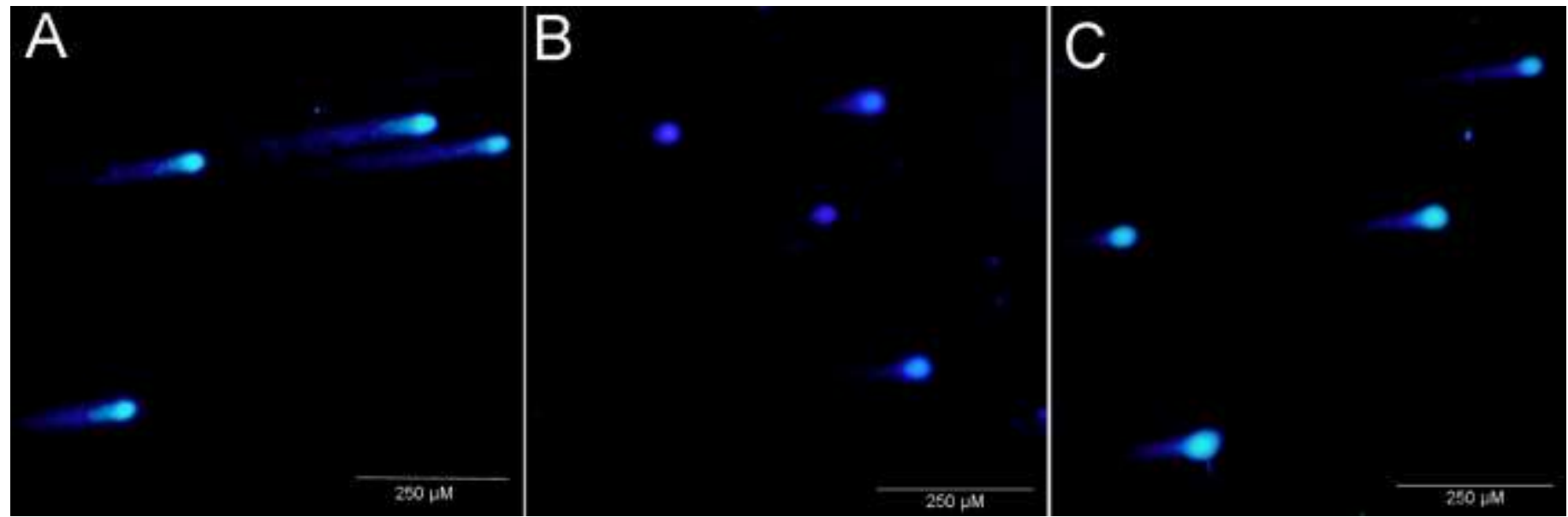

Figure 6. Comet images of curcumin and control groups in neoplastic transformed Balb/c 3T3 cells by sodium arsenite. (A) positive control group, (B) control group, (C) curcumin group. 


\section{DISCUSSION}

The action of arsenic in stimulating neoplastic cell transformation has been demonstrated by in vitro studies on various cell lines [24,25]. Human keratinocyte cells without tumor characteristics were applied to $100 \mathrm{nM}$ arsenite for 28 weeks, and malignant transformation was occurred [25]. In a previous study, arsenic compounds stimulated transformation in Syrian hamster embryo cells [26]. In another study, cells were exposed to $5 \mu \mathrm{M}$ arsenic for 10 weeks, the cells lost their contact inhibition ability and invasive property of the cells increased [27]. In the foci formation assay using Balb/c 3T3 cells, arsenic was found to stimulate transformation [28]. Arsenic compounds in transformation experiments showed an initiating effect of transformation. However, when TPA was added, cell transformation increased significantly in a dosedependent manner [19]. In a study conducted by Zhao and coauthors [8] rats were exposed to $0.5 \mu \mathrm{M}$ arsenic for eight weeks. As a result of the exposure, the cells were transformed, and their morphological structures had changes with neoplastic properties. In a study conducted by Stueckle and coauthors [29] BEAS-2B lung epithelial cells were exposed to chronic arsenic for six months. Cell proliferation, colony formation, cell invasion ability, and in vivo tumor formation potentials after exposure were compared to the control group and increased amount of reactive oxygen species was shown in the cells. This increase was reported to be effective in initiating cancer formation. In another study of human epidermal prostate cells, the cells were exposed to $5 \mu \mathrm{M}$ arsenic for 29 weeks and the transformation stages of the cells were examined. It was observed that the cells transformed to malignant cell [30]. In this study, Balb/c 3T3 embryonic fibroblast cells were exposed to $10 \mu \mathrm{M}$ sodium arsenite in the initial stage of a 32 days cell transformation experiment. In the second stage of the experiment, it was observed that the neoplastic change was increased by TPA. This result is consistent with previous transformation studies [19,27].

Many compounds derived from plants may be effective in the treatment of cancer. In addition, these natural compounds are less toxic than chemotherapeutic drugs. In vitro studies have shown that curcumin suppresses growth in many cancer cells [31-33]. Curcumin induces cell cycle arrest in cancer cells and provides apoptosis mediated cell death [34-36]. In a study of bladder cancer cells, the effect of curcumin on cell growth was evaluated and as a result, curcumin was found to decrease cell growth in dose and time dependent manner [37]. In another study, curcumin inhibited cell viability in human lung adenocarcinoma cell line [38]. Contrary to the studies mentioned, studies with healthy cells emphasize the proliferative effect of curcumin on various cell lines [39,40]. In murine splenocytes, sodium arsenite has been reported to significantly reduce cell viability, while curcumin has been noticed to increase cell viability [40]. In our study, it was found that curcumin did not cause any change in cell viability in 3T3 embryonic fibroblast cells, but decreased cell viability in neoplastic cells as a result of sodium arsenite-induced cell transformation. In a study with colorectal carcinoma cells, curcumin was applied to the cells at a concentration of $50 \mu \mathrm{M}$ and shown to cause DNA damage [41]. In a study of colonic cancer cells, curcumin was shown to induce cytotoxicity depending on dose and time [20]. In the present study, results showed that curcumin increased lactate dehydrogenase activity on neoplastic transformed Balb/c 3T3 embryonic fibroblast cells in concentration dependent manner. When the cells exposed to curcumin were compared with the control group, the increasing comet formation, a marker of DNA damage, was consistent with the previous studies $[41,20]$.

\section{CONCLUSION}

Consequently, results of the present study proposed that sodium arsenite induced neoplastic cell transformation and caused cells to acquire malignant cell character in Balb/c 3T3 embryonic fibroblast cells. In this context, daily arsenic exposure can trigger cancer formation and curcumin may decrease the cancer cell profile through increasing genotoxicity in neoplastic cells.

Funding: "This study was supported by Istanbul University Scientific Research Projects with the project number 25129". Conflicts of Interest: "The authors declare no conflict of interest."

\section{REFERENCES}

1. Yu HS, Liao WT, Chai CY. Arsenic carcinogenesis in the skin. J Biomed Sci. 2006;13(5):657-66.

2. Banik GN, Chakraborty I, Mukhopadhyay PK. Ameliorative effect of a-tocopherol and ascorbic acid on the accessory reproductive glands of adult male rats in arsenic toxicity. Int J Pharm Sci Rev Res. 2014;26(2):282-7.

3. World Health Organization. Arsenic and arsenic compounds. 2nd ed. World Health Organization, Geneva, Switzerland. Environ. Health Criteria. 2001;224. 
4. IARC. Arsenic in drinking-water, Lyon: International Agency for Research on Cancer. 2004;267.

5. Liu SX, Athar M, Lippai I, Waldren C, Hei TK. Induction of oxyradicals by arsenic: implication for mechanism of genotoxicity. Proc Natl Acad Sci. 2001;98(4):1643-48.

6. Benbrahim-Tallaa L, Waalkes MP. Inorganic arsenic and human prostate cancer. Environ Health Perspect. 2007;116(2):158-64.

7. Ding W, Hudson LG, Sun X, Feng C, Liu KJ. As (III) inhibits ultraviolet radiation-induced cyclobutane pyrimidine dimer repair via generation of nitric oxide in human keratinocytes. Free Radic Biol Med. 2008;45(8):1065-72.

8. Zhao CQ, Young MR, Diwan BA, Coogan TP, Waalkes MP. Association of arsenic-induced malignant transformation with DNA hypomethylation and aberrant gene expression. Proc Natl Acad Sci. 1997;94(20):1090712.

9. Kim HG, Shi C, Bode AM, Dong Z. p38a MAPK is required for arsenic-induced cell transformation. Mol Carcinog. 2016;55(5):910-7.

10. Ammon HP, Wahl MA. Pharmacology of Curcuma longa. Planta Med. 1991;57(01):1-7.

11. Gupta SC, Kismali G, Aggarwal BB. Curcumin, a component of turmeric: from Farm to Pharmacy. Biofactors. 2013;39(1):2-13.

12. Ravindran J, Prasad S, Aggarwal BB. Curcumin and cancer cells: how many ways can curry kill tumor cells selectively? AAPS J. 2009;11(3): 495-510.

13. Mukherjee S, Roy M, Dey S, Bhattacharya RK. A mechanistic approach for modulation of arsenic toxicity in human lymphocytes by curcumin, an active constituent of medicinal herb Curcuma longa Linn. J Clin Biochem Nutr. 2007;41(1):32-42.

14. Biswas J, Sinha D, Mukherjee S, Roy S, Siddiqi M, Roy M. Curcumin protects DNA damage in a chronically arsenicexposed population of West Bengal. Hum Exp Toxicol. 2010;29(6):513-24.

15. Wilken R, Veena MS, Wang MB, Srivatsan ES. Curcumin: A review of anti-cancer properties and therapeutic activity in head and neck squamous cell carcinoma. Mol Cancer. 2011;10(1):12.

16. Shehzad A, Wahid F, Lee YS. Curcumin in cancer chemoprevention: molecular targets, pharmacokinetics, bioavailability, and clinical trials. Arch Pharm. 2010;343(9):489-99.

17. Kunnumakkara $A B$, Anand $P$, Aggarwal $B B$. Curcumin inhibits proliferation, invasion, angiogenesis and metastasis of different cancers through interaction with multiple cell signaling proteins. Cancer Lett. 2008;269(2):199-225.

18. Takahashi M, Barrett JC, Tsutsui T. Transformation by inorganic arsenic compounds of normal Syrian hamster embryo cells into a neoplastic state in which they become anchorage-independent and cause tumors in newborn hamsters. Int J Cancer. 2002;99(5):629-34.

19. Tsuchiya $T$, Tanaka-Kagawa $T$, Jinno H, Tokunaga H, Sakimoto K, Ando M, et al. Inorganic arsenic compounds and methylated metabolites induce morphological transformation in two-stage BALB/c 3T3 cell assay and inhibit metabolic cooperation in V79 cell assay. Toxicol Sci. 2005;84(2):344-51.

20. Su CC, Lin JG, Li TM, Chung JG, Yang JS, Ip SW, et al. Curcumin-induced apoptosis of human colon cancer colo 205 cells through the production of ROS, $\mathrm{Ca}^{2+}$ and the activation of caspase-3. Anticancer Res. 2006;26(6B):437989.

21. Yang $\mathrm{H}$, Huang $\mathrm{S}$, Wei $\mathrm{Y}$, Cao $\mathrm{S}$, Pi C, Feng $\mathrm{T}$, et al. Curcumin enhances the anticancer effect of 5-fluorouracil against gastric cancer through down-regulation of $\mathrm{COX}-2$ and NF-KB signaling pathways. $\mathrm{J}$ Cancer. 2017;8(18):3697.

22. IARC/NCI/EPA Working Group. Cellular and molecular mechanisms of cell transformation and standardization of transformation assays of established cell lines for the prediction of carcinogenic chemicals: overview and recommended protocols. Cancer Res. 1985;45:2395-9.

23. Singh NP, McCoy MT, Tice RR, Schneider EL. A simple technique for quantitation of low levels of DNA damage in individual cells. Exp Cell Res. 1988;175(1):184-91.

24. Carpenter RL, Jiang $Y$, Jing $Y, H e J$, Rojanasakul $Y$, Liu LZ, et al. Arsenite induces cell transformation by reactive oxygen species, AKT, ERK1/2, and p70S6K1. Biochem Biophys Res Commun. 2011;414(3):533-8.

25. Pi J, Diwan BA, Sun Y, Liu J, Qu W, He Y, et al. Arsenic-induced malignant transformation of human keratinocytes: involvement of Nrf2. Free Radical Bio Med. 2008;45(5):651-8.

26. Lee TC, Oshimura M, Barrett JC. Comparison of arsenic-induced cell transformation, cytotoxicity, mutation and cytogenetic effects in Syrian hamster embryo cells in culture. Carcinog. 1985;6(10):1421-6.

27. Tokar EJ, Diwan BA, Waalkes MP. Arsenic exposure transforms human epithelial stem/progenitor cells into a cancer stem-like phenotype. Environ Health Perspect. 2009;118(1):108-15.

28. Landolph JR. Molecular mechanisms of transformation of $\mathrm{C} 3 \mathrm{H} / 10 \mathrm{~T} 1 / 2 \mathrm{C} 18$ mouse embryo cells and diploid human fibroblasts by carcinogenic metal compounds. Environ Health Perspect. 1994;102(3):119-25. 
29. Stueckle TA, Lu Y, Davis ME, Wang L, Jiang B, Holaskova I, et al. Chronic occupational exposure to arsenic induces carcinogenic gene signaling networks and neoplastic transformation in human lung epithelial cells. Toxicol Appl Pharmacol. 2012;261(2):204-16.

30. Achanzar WE, Brambila EM, Diwan BA, Webber MM, Waalkes MP. Inorganic arsenite-induced malignant transformation of human prostate epithelial cells. J Natl Cancer Inst. 2002;94(24):1888-91.

31. Chang CC, Fu CF, Yang WT, Chen TY, Hsu YC. The cellular uptake and cytotoxic effect of curcuminoids on breast cancer cells. Taiwan J Obstet Gynecol. 2012;51(3):368-74.

32. Liu D, You M, Xu Y, Li F, Zhang D, Li X, et al. Inhibition of curcumin on myeloid-derived suppressor cells is requisite for controlling lung cancer. Int Immunopharmacol. 2016;39:265-72.

33. Watson JL, Greenshields A, Hill R, Hilchie A, Lee PW, Giacomantonio CA, et al. Curcumin-induced apoptosis in ovarian carcinoma cells is p53-independent and involves p38 mitogen-activated protein kinase activation and downregulation of Bcl-2 and survivin expression and Akt signaling. Mol Carcinog. 2010;49:13-24.

34. Han X, Deng S, Wang N, Liu Y, Yang X. Inhibitory effects and molecular mechanisms of tetrahydrocurcumin against human breast cancer MCF-7 cells. Food Nutr Res. 2016;60(1):30616.

35. Kang JH, Kang HS, Kim IK, Lee HY, Ha JH, Yeo CD, et al. Curcumin sensitizes human lung cancer cells to apoptosis and metastasis synergistically combined with carboplatin. Exp Biol Med. 2015;240(11):1416-25.

36. Xia YQ, Wei XY, Li WL, Kanchana K, Xu CC, Chen DH, et al. Curcumin analogue A501 induces G2/M arrest and apoptosis in non-small cell lung cancer cells. Asian Pac J Cancer Prev. 2014;15(16):6893-8.

37. Shi J, Zhang X, Shi T, Li H. Antitumor effects of curcumin in human bladder cancer in vitro. Oncol Lett. 2017;14(1):1157-61.

38. Liu F, Gao S, Yang Y, Zhao X, Fan Y, Ma W, et al. Curcumin induced autophagy anticancer effects on human lung adenocarcinoma cell line A549. Oncol Lett. 2017;14(3):2775-82.

39. Yang B, Yin C, Zhou Y, Wang Q, Jiang Y, Bai Y, et al. Curcumin protects against methylmercury-induced cytotoxicity in primary rat astrocytes by activating the Nrf2/ARE pathway independently of PKCס. Toxicology. 2019; 425:152248.

40. Khan S, Vala JA, Nabi SU, Gupta G, Kumar D, Telang AG, et al. Protective effect of curcumin against arsenicinduced apoptosis in murine splenocytes in vitro. J Immunotoxicol. 2012;9(2):148-59.

41. Lu JJ, Cai YJ, Ding J. Curcumin induces DNA damage and caffeine-insensitive cell cycle arrest in colorectal carcinoma HCT116 cells. Mol Cell Biochem. 2011;354(1-2):247-52.

(C) 2021 by the authors. Submitted for possible open access publication under the terms and conditions of the Creative Commons Attribution (CC BY NC) license (https://creativecommons.org/licenses/by-nc/4.0/). 